\title{
Yeatsove maske in Pessoovi heteronimi v luči zahodnega ezoterizma
}

\section{Lara Gea Vurnik Navinšek}

Tesarska ulica 8, 1000 Ljubljana

https://orcid.org/0000-0003-2012-8178

lara.vurnik@gmail.com

\begin{abstract}
Članek obravnava vpliv zahodnega ezoterizma oziroma okultizma na življenje in delo Williama Butlerja Yeatsa in Fernanda Pessoe. Pri tem je posebna pozornost posvečena pesniški tehniki »kreativne disociacije " od lastnega jaza ali "depersonalizacije", kot je svojo heteronimijo označil Pessoa. Gre za bistveno skupno potezo Yeatsove in Pessoove poetike, ki ni le paradigmatsko modernistična, temveč tudi poudarjeno ezoterična. Kot ezoterične razumemo različne tokove, ki so se skozi zgodovino razvili vzporedno z organizirano religijo na eni in razsvetljenskim racionalizmom na drugi strani ter s tem tvorijo t. $i$. "tretji steber zahodne kulture". Yeatsovo teorijo maske so v veliki meri definirale tudi ideje, ki jih je pridobil v svojih letih članstva $v$ Hermetičnem redu Zlate zore, na nastanek Pessoovih heteronimov pa je vplivalo njegovo prakticiranje spiritizma, medijstva in avtomatskega pisanja. Delo obeh avtorjev tako lahko razumemo kot modernistični umetniški izraz, ki se je izoblikoval v tesnem kontaktu z zahodnim ezoterizmom.
\end{abstract}

Ključne besede: irska književnost / portugalska književnost / modernizem / Yeats, William Butler / Pessoa, Fernando / zahodni ezoterizem / okultizem / maska / heteronimi

I.

K razmišljanju o duhovnozgodovinskih premikih, ki so zaznamovali Evropo in njeno književnost ob prelomu 19. in 20. stoletja, lahko pristopamo na mnoge načine, med katerimi je med bolj zapostavljanimi vidik zahodnega ezoterizma. ${ }^{1}$ Ta sinkretični konglomerat različnih idej, gibanj, verovanj in praks se je v apokaliptičnem in vse bolj agnostičnem razpoloženju fin de siècla razcvetel v okultizmu, ki

\footnotetext{
${ }^{1}$ Termin »zahodni ezoterizem« se je v slovenskem strokovnem diskurzu že uveljavil kot prevod angleške zveze Western Esotericism oziroma francoskega l'ésotérisme occidental. Uporabljam ga namesto pojma "ezoterika«, prevzetega iz nemščine, ki je v splošni zavesti sicer bolj udomačen, vendar manj specifičen in nenatančno definiran.
} 
je $s$ svojo skrivnostnostjo in obrobnostjo privlačil številne umetnike. Poleg romantikov, simbolistov, dekadentov in kasneje nadrealistov sta med najbolj prepoznavnimi pisci, katerih življenje in delo je močno zaznamoval okultizem, tudi irski nobelovec William Butler Yeats in veliki portugalski modernistični pesnik Fernando Pessoa $s$ svojimi heteronimi.

Termin »zahodni ezoterizem (Western Esotericism)« se je v akademskem diskurzu pričel uveljavljati šele v 20. stoletju. Gre za umetno kategorijo, retrospektivno aplicirano na vrsto tokov in idej, ki so bile vsaj do konca 18. stoletja znane pod drugimi imeni (Hanegraaff, Western 3). Zaradi njegove heterogenosti je ta izmuzljivi teoretični konstrukt težko zadovoljivo definirati, na splošno pa velja, da gre za ideje, ki se odmikajo tako od ortodoksne judovsko-krščanske tradicije kot razsvetljenskega racionalizma ter $\mathrm{s}$ tem tvorijo "tretji steber zahodne kulture«. To je oznaka, ki jo v svoji definiciji uporabi zgodovinar religije Henrik Bogdan. Po njem je ezoterizem tretja oblika védenja, ki je zavzemala središčno mesto med znanstveno racionalnostjo in religioznostjo ter bila hkrati zavrnjena od obeh - zagovorniki prve so ezoterizmu zamerili domnevno iracionalnost in nagnjenost $\mathrm{k}$ metafizičnemu argumentiranju, dogmatična verska doktrina pa ga je obtoževala herezije (glej Hanegraaff, Western 7). Duhovna podlaga teh idej se je sicer formirala $\mathrm{v}$ pozni antiki, ko je bil duh časa naklonjen religijskemu sinkretizmu in eklekticizmu. V Aleksandriji sta se razvijali astrologija in alkimija, vzporedno $\mathrm{z}$ judovstvom in vzponom krščanstva pa so se pojavili alternativni duhovni in miselni tokovi, kot so hermetizem, novoplatonizem in gnosticizem. Po Hanegraaffu v poskusih konceptualizacije zahodnega ezoterizma prevladujejo trije glavni modeli. Običajno je razumljen kot: (1) "čaren" ali "očaran (enchanted) « predrazsvetljenski duhovni nazor s starodavnimi koreninami, ki se je razcvetel v zgodnjem novem veku; (2) širok razpon "okultnih" tokov in organizacij, ki so se pojavile po koncu razsvetljenstva kot alternative tradicionalni religiji in racionalni znanosti; (3) univerzalna, "notranja» duhovna dimenzija religije same po sebi $^{2}(4-5)$. Čeprav imajo vsi trije načini razumevanja svojo vlogo pri opredeljevanju fenomenov kot ezoteričnih, Hanegraaff sam zagovarja

${ }^{2}$ Zadnji pristop je po Hanegraaffu najbolj problematičen, saj med drugim predpostavlja dejanski obstoj takšne skrite dimenzije, ki je ni mogoče empirično obravnavati (Hanegraaff, Western 11). Poleg tega taka opredelitev ezoterizma odpira tudi kočljivo vprašanje odnosa med ezoterizmom in misticizmom, med katerima se meje pogosto zdijo zamegljene. Faivre kot eno od možnih razlik predlaga pojem mediacije, saj mistik običajno zavrača posredništvo med sabo in božjim (Faivre 12). 
sodobnejši, pluralistični pristop, ki ne daje prednosti nobenemu zgodovinskemu obdobju ali svetovnemu nazoru (12).

$\mathrm{Na}$ splošno velja, da so se ideje, ki predstavljajo t. i. »osnovni referenčni korpus" zahodnega ezoterizma oblikovale v renesansi, ko se je Evropa obrnila nazaj $\mathrm{k}$ svojim antičnim koreninam in so se pojavile tendence spajanja nekrščanskih oziroma poganskih elementov s krščansko mistiko in kabalo (Hanegraaff, Western 25). Antoine Faivre v svoji vplivni definiciji predlaga, da je ezoterizem mogoče identificirati na podlagi štirih bistvenih in dveh sekundarnih lastnosti. Tako je za ezoterične pojave značilno četverno verovanje: $\mathrm{v}$ nevidno, presežno dimenzijo obstoja, ki korespondira z vidno, materialno; v oživljeno naravo kot fizično manifestacijo te dimenzije; $\mathrm{v}$ moč človeške domišljije in simbolnega obredja kot orodij za posredovanje med obema dimenzijama; in posledično $v$ to, da se je posameznik $s$ pomočjo teh orodij in skozi transmutacijo lastne biti zmožen približati transcendenci ali se z njo celo združiti. Sekundarni sestavini sta odkrivanje skupnih imenovalcev med različnimi duhovnimi tradicijami z namenom najti prvobitno metafizično resnico in prenašanje ezoteričnega znanja $\mathrm{z}$ učitelja na učenca prek procesa iniciacije (Faivre 10-15). Elemente naštetih verovanj lahko razberemo tudi v Yeatsovem in v Pessoovem delu. Tako lahko z ozirom na čas, $\mathrm{v}$ katerem sta delovala, govorimo o ezoteričnih, pa tudi okultnih oziroma okultističnih vplivih, vendar se je treba zavedati, da nam takšno rabo dopušča kontekst, saj ne gre za popolno semantično prekrivanje.

Termin "okultizem" je sicer dolgo veljal za ekvivalent, tako rekoč sinonim ezoterizmu; do razločevanja je prišlo šele v zadnjih desetletjih. Med glavnimi zagovorniki distinkcije je tudi Hanegraaff, ki ga obravnava kot posebno razvojno obliko in $s$ tem podpomenko ezoterizma (Hanegraaff, New 385). Žarišči novonastalih ali ponovno definiranih gibanj, ki jih je mogoče umestiti pod ta krovni pojem, sta bili v drugi polovici 19. stoletja predvsem Francija in Velika Britanija, dva še posebej vplivna posameznika tega obdobja pa Eliphas Lévi in Helena Petrovna Blavatsky. Lévi je s svojimi spisi v veliki meri določil prakso kabalistične magije, ki jo je v okrilju Hermetičnega reda Zlate zore prakticiral tudi Yeats, Madame Blavatsky pa je v ZDA utemeljila moderno teozofijo, ki zahodni ezoterizem združuje z vzhodnimi (predvsem budističnimi in hindujskimi) verovanji. Tako Yeats kot Pessoa sta svojo ezoterično pot pričela $\mathrm{v}$ okviru teozofije, kasneje pa sta zanimanje oba preusmerila predvsem $\mathrm{k}$ alkimiji, gnosticizmu, hermetizmu in hermetični kabali ter idejam iniciacijskih redov, ki naj bi si za zgled jemali mitično rožnokrižarsko bratovščino. 
II.

Williama Butlerja Yeatsa poznamo kot enega najeminentnejših literatov na prelomu 19. in 20. stoletja, prejemnika Nobelove nagrade za književnost, na Slovenskem pa predvsem kot pesnika, čeprav njegov opus zajema tudi številna krajša prozna dela, drame in eseje. Šele v zadnjih nekaj desetletjih ga zares spoznavamo tudi kot velikega ezoteričnega misleca, ki je evropski okultizem fin de siècla sprejel tako rekoč za osebno "religijo«. Danes ni več dvoma, da je se je Yeats s tem duhovnim nazorom istovetil praktično vse življenje, vendar je literarna veda dolgo podcenjevala, ignorirala ali celo zatajevala dejanski pomen ezoteričnih prepričanj in praks za njegovo delo. K temu je nekoliko pripomogel tudi Yeats sam, ki je omilil okultistične reference v svojem pisanju po opozorilu urednika, češ da katoliška irska javnost njegovo delo doživlja kot heterodoksno. Sčasoma pa je postalo jasno, da se ni mogoče povsem približati Yeatsu kot pesniku, če ne vzamemo resno tudi Yeatsa kot maga, saj sta bili pri njem obe praksi v resnici tesno prepleteni.

V primerjavi z Yeatsom je bil Fernando Pessoa kljub svojim mističnim izkušnjam verjetno večji skeptik. Čeprav je intenzivno raziskoval različne ezoterične sisteme, bil aktiven in nadarjen astrolog ter prakticiral spiritizem in medijstvo, je bil njegov odnos do teh »okultnih znanosti« ambivalenten. Tudi Bergles v spremni besedi h Camposovi Pomorski odi pripominja: "Pessoa je bil prevelik analitik, da bi se brez pomislekov vdajal okultizmu, čeprav ga je ta vznemirjal« (65). Ne glede na pomisleke ga je okultizem pomembno zaznamoval in bil najverjetneje povezan tudi s formulacijo heteronimije - najbolj prepoznavne plati Pessoovega ustvarjanja, ki je hkrati temeljno določilo njegovega modernizma.

Znano je, da si je Pessoa avtorstvo svojih del delil z več kot sedemdesetimi "heteronimi«, med katerimi mnogi niso bile zgolj poimenovani, temveč so imeli tudi dodelan značaj, videz, biografijo, včasih celo astrološko rojstno karto. Najbolj produktivni med njimi so bili Alberto Caeiro, Ricardo Reis in Álvaro de Campos; čeprav tudi pri njih najdemo mnoge ezoterične reference, pa je največji ezoterik »Pessoa sam". Kot v kritiki Knjige nespokoja (Livro do Desassossego) zapiše George Steiner: "nihče iz te triade ni primerljiv z metafizično samoto, občutkom biti okultistični medij, ki je značilna za Pessoove 'lastne' intimne verze« (Steiner, »A Man«). Zanimivo je, da je bila večina Pessoovih ezoteričnih zapisov napisana brez posredništva heteronimov (Suaréz 245) in $\mathrm{v}$ angleščini, jeziku, $\mathrm{v}$ katerem je bral večino ezoteričnih virov, in ki je bil hkrati tudi zmeraj jezik njegovih najbolj intimnih razmišljanj (Pasi, »The Influence« 695). 
Patricia Silva McNeill ugotavlja, da se Pessoo z razlogom vzporeja z Yeatsom, čeprav se zdi primerjava na prvi pogled nekoliko nepričakovana. Oba sta med drugim izhajala iz manjših zahodnoevropskih narodov (irskega in portugalskega), ki sta prestajala literarno reformo sočasno z njunimi lastnimi pesniškimi začetki, bistvena skupna točka pa je poleg pesniških "mask« in literarnega nacionalizma tudi zanimanje za okultizem (McNeill, Yeats 1). Čeprav gre podobnosti prej kot neposredni recepciji pripisati duhu časa, podobnim svetovnim nazorom in estetskim okusom ter istim vplivom, ki so delovali na oba, Yeatsovega vpliva na Pessoo ne moremo povsem izključiti. V Pessoovi osebni knjižnici najdemo tri Yeatsova dela in očitno je z njim na neki točki celo želel vzpostaviti stik, o čemer priča neodposlano pismo v njegovi zapuščini. Zanimala ga je Yeatsova pobuda za irski literarni preporod, ki ga je videl kot predhodnika podobno motivirani "portugalski renesansi (Renascença Portuguesa) « (McNeill, Yeats 1-3). Pessoov odnos do starejšega pesnika sicer ni povsem jasen, saj se zdi, da ga je po eni strani (vsaj nejevoljno) spoštoval, hkrati pa večkrat kritiziral. Izdelal in preučeval je tudi Yeatsovo astrološko rojstno karto, ki ga je verjetno še posebej fascinirala zato, ker je bil rojen na isti dan (13. junija, triindvajset let pred njim). Iz dopisov z drugim črnilom je razvidno, da se je k njej vrnil po letu 1923, ko je Yeats prejel Nobelovo nagrado, in poskušal iz nje razbrati astrološke okoliščine tega dogodka (McNeill, "Sacred « 24-26).

Tudi Yeatsova in Pessoova ezoterična pot sta si bili sicer v mnogih pogledih podobni. Oba sta že $\mathrm{v}$ otroštvu čutila naravnanost $\mathrm{k}$ transcendentnemu, vendar sta se hkrati počutila odtujena od prevladujoče oblike krščanstva v svojem času in okolju (irskega protestantizma in portugalskega katolicizma). Ni nenavadno, da sta se oba z ezoteričnimi idejami pričela intenzivneje ukvarjati v okviru teozofije, saj je bila ta najlaže dostopna in v splošni zavesti tudi najmanj problematična, vendar sta se oba od nje tudi kmalu oddaljila. Yeats je Madame Blavatsky tudi osebno poznal in bil nekaj časa član Teozofskega društva, dokler ni z njo prišel v konflikt zaradi prevelikega zanimanja za prakticiranje magije. Bala se je namreč, da bi s tem ogrozil Teozofsko društvo, ki si je prizadevalo, da bi bilo čim širše družbeno sprejeto. Pessoa je po drugi strani v letih 1915 in 1916 v portugalščino prevedel več del vodilnih teozofov, kasneje pa je do gibanja postal močno kritičen, ker se mu je zdelo preveč demokratično, medtem ko bi morale biti po njegovem mnenju ezoterične skrivnosti razkrite samo izbrancem. Motilo ga je tudi vnašanje elementov vzhodne duhovnosti in filozofije. Verjel je, da jih um, oblikovan z zahodnimi vrednotami, ne more zares doumeti, in 
se hkrati bal, da teozofija s svojim sinkretizmom kontaminira evropsko hermetično izročilo.

Tako ali drugače razočarana nad teozofskimi nazori sta se oba, Yeats in Pessoa, pričela zanimati za druga ezoterična gibanja. Yeats je bil iniciiran v Hermetični red Zlate zore, angleško magijsko organizacijo, utemeljeno na sistemu hermetične kabale ${ }^{3}$ in osredotočeno na prakso ceremonialne magije $s$ ciljem duhovnega razvoja. Izbral si je magijski moto Daemon Est Deus Inversus in bil v redu odtlej znan kot "Frater D. E. D. I..$^{4}$ Leta 1893 je dosegel stopnjo manjšega adepta, Adeptus Minor oziroma 5=6, po pričevanju njegove žene pa naj bi napredoval celo vse do $7=4 .{ }^{5}$ Vsekakor je v duhovnem okrilju Zlate zore razvijal svojo misel več desetletij. Rezultat je bil njegov magnum opus, ezoterično-filozofsko-zgodovinsko-poetološki konglomerat Vizija (A Vision), ki ga je sam opredelil kot »razlago življenja«. Čeprav z delom nikoli ni bil povsem zadovoljen in je zato tudi izšlo $\mathrm{v}$ dveh povsem različnih verzijah (Vizija $A$ leta 1925 in Vizija $B$ leta 1937), se je z njim še najbolj približal temu, da bi razvil lastni ezoterični sistem. Brez tega ozadja je zelo težko zadovoljivo razumeti velik del njegovega opusa, saj je okultizem za Yeatsa postal neizčrpna zakladnica simbolov, ki so postali vezivo njegove poezije.

Kolikor vemo, Pessoa nikoli ni pripadal nobenemu redu, čeprav se je nanje pogosto navezoval v svojem pisanju. Najbolj skrivnosten med njimi je Templjarski red Portugalske (Ordem Templária de Portugal), saj o njem za zdaj ni dokazov, da bi kadarkoli dejansko obstajal (Pasi, Aleister 105). Pessoa o njem govori zgolj kot o »izumrlem" ali "mirujočem « in pravi celo, da je imel vpogled v obredje prvih treh manjših stopenj "prek neposredne komunikacije med Mojstrom in Učencem" ter bil na ta način v red tudi iniciiran (Pessoa, "Nota«). Po drugi strani

${ }^{3}$ T. i. »hermetična kabala« se je razvila v renesansi kot poskus združitve judovske kabale $s$ filozofijo hermetizma. Gre za tipično sinkretičen konglomerat različnih sistemov z elementi gnosticizma, novoplatonizma, poganskih religij, astrologije in alkimije.

${ }^{4}$ Magijski moto je psevdonim, pod katerim delujejo člani magijskih redov. Njegov namen je razločiti posameznikovo magijsko identiteto od vsakdanje. Navadno ima obliko kratkega gesla v tujem jeziku, največkrat v latinščini. Člani se medsebojno naslavljajo s frater (lat. "brat") in soror (lat. "sestra») ter se tako tudi podpisujejo, čemur sledi kratica, sestavljena iz prvih črk magijskega mota.

${ }^{5}$ Hierarhična struktura Zlate zore je bila sestavljena iz enajstih stopenj, od neofita na stopnji $0=0$ do $10=1$, najvišje in najbolj razsvetljene stopnje, ko naj bi adept prejel naziv Ipsissimus. Druga številka v oznaki stopnje predstavlja položaj na kabalističnem drevesu življenja, kjer so božje emanacije stvarstva reprezentirane vertikalno od desete in najnižje, Malkut, fizičnega obstoja, do prve in najvišje, Keter, prvobitnega svetlobnega počela. 
je vsaj na dveh mestih zatrdil, da ni član nobene rožnokrižarske, prostozidarske ali druge ezoterične organizacije, vendar vemo tudi, da se po njegovem mnenju pravi rožni križar nikoli ne deklarira javno (Dix 12). Obstaja utemeljen sum, da je Aleister Crowley nameraval ustanoviti portugalski sedež svojega reda Ordo Templi Orientis in ga prepustiti v vodstvo Pessoi, saj o tem piše v svojem dnevniku (Pasi, Aleister 104). Crowley, med drugim bivši član Zlate zore in ustanovitelj religije Thelema, je v Yeatsovem življenju predstavljal antagonistično figuro, medtem ko ga je Pessoa občudoval in z njim celo prijateljeval. Kot izkušen astrolog je odkril napako v Crowleyjevi rojstni karti, natisnjeni na začetku njegove avtobiografije, in na to opozoril založnika. Crowleyjeva pisna zahvala Pessoi je pripeljala do dopisovanja in septembra 1930 do njegovega obiska Portugalske, ki je postala prizorišče intrigantne zarote. Crowley je namreč s Pessoovo pomočjo uprizoril lažni samomor: pri breznu Boca do Inferno v klifih blizu Cascaisa je pustil skrivnostno poslovilno pismo in kmalu zatem zapustil Portugalsko, Pessoa pa je podal javno izjavo, da je njegov prijatelj nepojasnjeno izginil. Iz vsebine Pessoovih poznejših ezoteričnih zapisov je razvidno, da je imela Crowleyjeva telemistična doktrina $\mathrm{v}$ zadnjih letih življenja na njegovo misel močan vpliv (Pasi, »The Influence« 711).

Nazadnje Yeatsa in Pessoo povezuje tudi izkušnja spiritizma in medijstva oziroma avtomatskega pisanja. Tudi Yeatsova Vizija je nastala kot kombinacija njegovega lastnega ezoteričnega znanja in "nareka" iz onstranstva, saj naj bi njegova žena, Georgie Hyde-Lees, stopila v kontakt z breztelesnimi entitetami, ki jih Yeats imenuje "sporočevalci«. Pessoa pa se je v mladosti s svojo teto udeleževal spiritističnih seans in nato sam pogosto eksperimentiral z medijstvom in avtomatskim pisanjem. Tudi on je verjel, da navezuje stik z nečim ločenim od samega sebe, predvsem duhovi umrlih sorodnikov in zgodovinskih osebnosti. Entitete, $s$ katerimi je komuniciral, je kasneje identificiral prek podpisov in jih večinoma doživljal kot svoje učitelje oziroma duhovne mentorje. Med njimi so bili cambriški platonist Henry More in njegov kolega, poimenovan zgolj "Wardour ", pa tudi temačna, zla figura Voodooist, ki se je včasih predstavila kot Giuseppe Balsamo (pravo ime grofa Alessandra di Caliostra). Avtomatizem je pričel prakticirati približno istočasno kot zakonca Yeats, Patricia S. McNeill pa opaža tudi podobnost med geometrijskimi skicami v Viziji in tistimi v avtomatskih zapisih iz Pessoovega arhiva, kar razlaga kot zavestno ali nezavedno reproduciranje zlatozorskih simbolov (McNeill, »The Alchemical« 161). Ker so bili člani reda zaobljubljeni k molčečnosti, Pessoa v nasprotju z Yeatsom sicer ni imel neposrednega dostopa do zlatozorskih skrivnosti; vemo pa, da je prebiral 
A. E. Waita, enega najvidnejših članov reda, predvsem njegova dela na temo rožnokrižarstva in prostozidarstva (Dix 13-14).

O Pessoovih izkušnjah z medijstvom veliko izvemo iz njegovega pisma teti Anici (24. 6. 1916). Med drugim ji pripoveduje, da naj bi pridobil »eterični« ali »astralni« vid - zmožnost videnja človeške avre in da ponoči doživlja nenavadne vizije figur, slik, simbolov in števil. Poleg tega naj bi začutil, ko je prijatelj in pesnik Mário de Sá-Carneiro doživljal globoko psihološko krizo, ki ga je privedla do samomora. Včasih je imel tudi občutek, da ne pripada samemu sebi (opisuje, kako se mu roka dvigne sama od sebe ali pade na bok, kot bi bil "magnetiziran" oziroma hipnotiziran) in v zrcalu je pričel videvati tuje obraze: "[...] večkrat, kadar gledam $\mathrm{v}$ zrcalo, moj obraz izgine in pojavi se obraz bradatega moža ali koga drugega (štirje so vsega skupaj, ki se mi tako prikazujejo) «(Pessoa, "Carta à Tia«). Pessoa je bil na splošno nestabilnega psihičnega zdravja in je živel v konstantnem strahu pred blaznostjo. Že pri šestih letih je samemu sebi pisal pisma kot nekdo drug in od tedaj naprej živel z množico glasov, diskurzov in osebnosti, ki so ga včasih spravljale ob pamet (Kotowicz 15). Zbigniew Kotowicz Pessoovo pluralnost, posledično pa vznik heteronimije (izkustva, ki jih imenuje "metempsihotični fenomeni«), upravičeno poveže s fascinacijo nad okultizmom (prav tam), saj jih tudi Pessoa sam ni zmeraj doživljal kot psihološko anomalijo, temveč tudi kot iniciacijske preizkušnje ob prehajanju na novo stopnjo zavesti. "Kar se tiče duševnega ravnovesja, sem dobro kot še nikoli«, zatrjuje tudi v pismu teti Anici:

Dovolj že vem o okultnih znanostih, da sem znotraj sebe sposoben prepoznati prebujanje tako imenovanih višjih čutov za nekakšen cilj, kakršen že bodi, in to, da mi bo neznani Mojster, ki me iniciira tako, da mi nalaga višji obstoj, dal [...] občutiti tisti globoki gnus nad vsem, ki pride s povečanjem sposobnosti (Pessoa, "Carta à Tia»).

Yeats in Pessoa sta pesniški postopek doživljala izrazito metafizično in si prizadevala priti do najvišjih izrazov poezije, ki sta jo razumela kot most $\mathrm{k}$ presežni resničnosti. Zato sta oba intenzivno eksperimentirala $s$ slogom in pri tem navdih črpala iz podobnih virov, med najpomembnejšimi pa so bili tudi tisti, ki jih lahko umestimo na področje zahodnega ezoterizma. Ta ezoteričnost odseva predvsem v pesniškem podobju, od rožnokrižarske simbolike do mitično-ezoteričnega nacionalizma Yeatsove pesnitve Oisinove blodnje (The Wanderings of Oisin) in Pessoovega cikla Sporočilo (Mensagem), odkriti pa jo mogoče tudi v ozadju pesniške tehnike "depersonalizacije (kot svoje pisanje skozi heteronime imenuje Pessoa sam). Gre za bistveno skupno potezo 
Yeatsove in Pessoove poetike, ki ni le paradigmatsko modernistična, temveč tudi poudarjeno ezoterična.

III.

Patricia S. McNeill Yeatsovo uporabo mask in Pessoovo heteronimijo označi za analogni pesniški strategiji, ki se razlikujeta le $\mathrm{v}$ stopnji, in ju komentira prvenstveno kot vnos dramatskih elementov v lirsko poezijo, da bi se čim bolje izrabil njen ekspresivni potencial (McNeill, Yeats 128). V kasnejši razpravi o ezoteričnih vplivih na delo obeh pesnikov pa tehniki metaforično poveže $\mathrm{z}$ alkimistično transmutacijo osebnosti (McNeill, "The Alchemical « 166). Z ezoteričnega vidika k heteronimiji pristopa tudi Marco Pasi skozi koncepta »odtujeno delovanje (alienated agency)« in »kreativna disociacija (creative dissociation)«. Odtujeno delovanje opredeljuje kot orodje za pristopanje k umetnikovi izkušnji kontakta z osebnostmi, ki jih doživlja kot subjektivne, neodvisne in ločene od svojega običajnega, zavestnega jaza, pri čemer je končno avtorstvo dela, navadno močno inovativnega ali radikalnega umetniškega diskurza, pripisano tem entitetam (Pasi, "Hilma« 113). Disociacija je sicer povsem običajen mentalni pojav, kadar za nekaj trenutkov pozabimo na same sebe (npr. med gledanjem televizije ali kadar smo na "avtomatskem pilotu" pri rutinskih aktivnostih). Tudi depersonalizacija je oblika disociacije, pri kateri se subjekt čuti odtujenega od lastnega telesa ali uma, kot bi samega sebe opazoval od zunaj. Kadar so takšna stanja ekstremna ali kronična, so v zahodni psihologiji in psihiatriji večinoma razumljena kot patološka in kot posledica pretekle travme, vendar nekateri psihologi opozarjajo, da je način interpretiranja vezan na kulturno okolje: »kar je videti kot nepovezanost ali fragmentacija, je morda dejansko uvod v presežno celovitost ali višjo integracijo« (Grosso 182). To stanje, ki ga ameriški psiholog Michael Grosso poimenuje »kreativna disociacija», je paradoksno, saj je hkrati dekonstruktivno in rekonstruktivno: preden se subjekt lahko "reasociira" na višjem nivoju, se mora "disociirati" od nekaterih aspektov nižjega sebstva ali običajnega sveta. Kot tri medsebojno povezane tipe kreativne disociacije Grosso navaja inspiracijo (npr. antično razumevanje muz), medijstvo in nadrealizem (182). K primerom, ki jih obravnava (Blake, Mozart, Nietzsche, Rimbaud) bi zlahka dodali Pessoo, pa tudi Yeatsa. Čeprav bolj subtilen, je mehanizem kreativne disociacije še zmeraj jasno razviden iz njegove teorije o pridobivanju umetniškega navdiha, tesno povezane $s$ konceptom maske. 
Richard Ellmann ugotavlja, da "Yeats ni odrasel s preprostim videnjem lastnega značaja; že kot deček je začel pred svetom nastopati kot nekaj drugega kakor to, kar je $\mathrm{v}$ resnici bil, in je do pozne adolescence že razmišljal o sebi kot razdeljenem na dvoje (Ellmann, "Robartes« 178). Podobno čuti neimenovani pripovedovalec "Rose Alchemice«, ene izmed Yeatsovih najbolj ezoteričnih zgodb: »celo v svojem najbolj popolnem trenutku sem bil dva jaza, in eden je s težkimi očmi opazoval zadovoljni trenutek drugega" (Yeats, "Rosa" 128). Yeats se je vse življenje zavedal ne le svoje lastne dvojnosti, temveč tudi antitetičnosti osnovnih gibal obstoja. Sistem Vizije je po njegovih besedah "utemeljen v verovanju, da se temeljna resničnost [...] spušča v človeško zavest v seriji antinomij" (Yeats, A Vision 137). Celotno sumo bivanja je doživljal kot medsebojno učinkovanje nasprotij, ki je po principu hermetičnih korespondenc vsebovano $\mathrm{v}$ vsakem posamezniku in se zrcali $\mathrm{v}$ človeški zgodovini. Razcepljenost identitete, ki ima za posledico pluralnost jazov, torej ni močno vznemirjala le Pessoe, temveč tudi Yeatsa, maska pa je bila za to občutje idealen simbol.

Kot pravi Susan Johnston Graf, je Yeats prva leta 20. stoletja preživljal nekakšno "temno noč duše«, med drugim zaradi nesoglasij znotraj Zlate zore. ${ }^{6}$ Yeats je bil v tem obdobju prepričan, da ga je dokončno zapustil navdih - ali kakor ga je imenoval sam, - daemon, vse dokler ni razvil svoje teorije maske. Temu je leta 1917 sledila dokončna artikulacija poetike v eseju Per Amica Silentia Lunae (PASL), zatem pa pesmi, ki so mu prinesle sloves velikega modernističnega pesnika. Tako so bile za Yeatsa maske, podobno kot za Pessoo heteronimi, prelomnega pomena pri formulaciji inovativnega in prepoznavnega ustvarjalnega izraza, hkrati pa se jim ne moremo povsem približati brez konteksta Yeatsovih ezoteričnih idej. Najbolj strnjeno in deklarativno jih je izpovedal na začetku zgodnjega eseja "Magija«:

Verjamem v prakso in filozofijo tega, za kar smo se dogovorili, da bomo imenovali magija, v to, kar moram imenovati evokacija duhovnih bitij, čeprav ne vem, kaj so, v moč ustvarjanja magijskih iluzij, v vizije resnice v globinah uma, ko so oči zaprte; in verjamem v tri doktrine, za katere mislim, da so nam bile predane iz zgodnjih časov in so bile temelj skoraj vseh magijskih praks. Te doktrine so: -

(1) Da se meje našega uma ves čas premikajo in da se mnogo umov lahko tako rekoč steka drug v drugega, da bi ustvarili ali razkrili enoten um, enotno energijo.

${ }^{6}$ Leta 1899 so izključili Crowleyja (med njegovimi najbolj odločnimi nasprotniki je bil prav Yeats), zaostrovanje konfliktov pa je na koncu privedlo do shizme, ki je pomenila konec reda, kakor je bil izvorno zasnovan. 
(2) Da se meje naših spominov premikajo in da so naši spomini del enega samega velikega spomina, spomina Narave same.

(3) Da ta veliki um in veliki spomin lahko prikličemo s simboli (25).

V PASL Yeats ta veliki, enotni um po (novo)platonističnem zgledu poimenuje anima mundi, svetovna duša. Individualne človeške duše razume kot »kondenzacijo anime mundi« (65), ki je ne vidi le kot oživljajoče počelo, temveč tudi v tako rekoč jungovskem smislu kot kozmični spomin, arhiv vseh individualnih človeških spominov. Yeatsovo koncipiranje anime mundiv PASL lahko povežemo s tremi izmed štirih temeljnih karakteristik ezoterizma po Faivreju, ki jim deloma ustrezajo tudi doktrine, navedene $\mathrm{v}$ »Magiji«: (1) podobe, ki vznikajo v zavesti posameznika, korespondirajo s tistimi v animi mundi; (2) predstavljena je kot sila, ki oživlja naravo; (3) kot sredstvo za dostopanje $\mathrm{k}$ njej služijo simbolne podobe. Takšno sredstvo je bila za Yeatsa, ki je v svetovni duši videl neusahljiv vir simbolov za svojo poezijo, tudi praksa ceremonialne magije. Koncept svetovne duše je tako bistvenega pomena za Yeatsov pesniški postopek, saj je zanj predstavljal tisto skrivnostno dimenzijo, od koder prihaja pesniški navdih.

Pridobivanje inspiracije je po Yeatsu povezano s tremi faktorji, ki jih imenuje daemon, "antijaz (anti-self) « in "maska». Če je anima mundi izvor navdiha, je daemon njegov nosilec, tisto, kar mora pesnik priklicati pred začetkom pesniškega postopka; sredstvo za to evokacijo je lahko tudi magijski ritual. Yeatsov daemon je v nekaterih pogledih primerljiv z božanskim "višjim jazom «, s katerim so si prizadevali stopiti v stik adepti Zlate zore; opisuje ga kot razsvetljeno bitje, ki je doseglo duhovno popolnost (Johnston Graf 69). Daemona po Yeatsu privlači človekovo nasprotje, saj je tudi sam po svoji naravi človeku nasproten ter ga s tem dopolnjuje: "človek in daemon hranita lakoto v srcih drug drugega« (Yeats, Per 37). To nasprotje, ki k človeku pritegne njegovega daemona, Yeats kasneje poimenuje antijaz, svoj antijaz pa pesnik lahko utelesi tako, da se skrije za masko.

K Yeatsovi fascinaciji je zagotovo prispevalo tudi obredje Zlate zore. Zanimivo je primerjati Yeatsovo teorijo z Regardiejevimi navodili za zaključni korak enega izmed evokacijskih ritualov, ki vključuje vizualizacijo "astralne« maske: "Zdaj naj si Mag predstavlja, da je navzven oblečen v podobnost forme Duhovnega bitja [Spirit], ki ga priklicuje, in pri tem naj bo previden, da se ne identificira z bitjem, kar bi bilo nevarno, temveč da le oblikuje vrsto maske, ki jo bo nosil začasno" (Regardie 381; prim. Johnston Graf 110-111). ${ }^{7}$ Poleg tega je bila

${ }^{7}$ Israel Regardie, član Zlate zore in kasnejše sekcije Stella Matutina, je iz strahu, da bi njihov magijski sistem utonil v pozabo, prekršil zaobljubo ter med leti 1938 in 1940 javno objavil rituale. 
postopna formulacija mask povezana $\mathrm{z}$ Yeatsovim obnovljenim zanimanjem za spiritizem. Leta 1911 se je na domu nekega ameriškega medija soočil z glasom, ki se je predstavil kot Leo Africanus (Yeats naj bi šele kasneje ugotovil, da ime pripada mavrskemu pisatelju in raziskovalcu iz 16. stoletja) in trdil, da je njegov drugi jaz ali »maska«. Njuno neobjavljeno dopisovanje sugerira, da je velik del Vizije povezan tudi s to izkušnjo (Flannery 128). Nazadnje so se maske udejanjile tudi v Yeatsovem pisanju, včasih na skoraj protoheteronimičen način. Yeatsova literarna dela namreč naseljujejo pogosto ponavljajoči se zgodovinski ali fiktivni, prevzeti ali izvirni, neimenovani ali imenovani lirski subjekti in liki. Med njimi so Oisin, mitični irski pesnik kralj Fergus, grofica Cathleena, kralj Salomon, Michael Robartes, Owen Aherne, Owen Red Hanrahan, nora Jane, blazni stari Tom in Ribh, heretični srednjeveški keltski menih, po katerem je Yeats napisal cikel »Nadnaravne pesmi (Supernatural Songs)«. Kot pravi Ellmann: "Domišljijsko ali dejansko, tako ali drugače so Leo Africanus in vsi drugi duhovi obstajali in Yeats je z njimi napolnil svojo poezijo. [...] Pesnik manj pogosto govori v svoji lastni osebi, temveč uporablja berače, puščavnike in norce, da varno izrazi mnenja o življenju in posmrtnem življenju, za katera ni pripravljen jamčiti« (Ellmann, Yeats 205). ${ }^{8}$ Ellmannovo razumevanje namena Yeatsovih mask torej ustreza Pasijevi opredelitvi odtujenega delovanja.

Podobnost med maskami in heteronimi ni ostala neopažena, v primerjavi pa gresta zagotovo najdlje Hamid Ghahremani Kouredarei in Nahid Shahbazi Moghadam. Kot pravita, uporaba person, kakršne so Yeatsove maske, sama po sebi ni unikatna, vendar so nekatere več kot le to: $\mathrm{v}$ likih Robartesa, Aherna in Hanrahana avtorja odkrivata "globlji in novejši slog izdelave mask, [...] podoben Pessoovemu konceptu heteronimov« (Kouredarei in Moghadam 359). V nekaterih pesmih namreč zaznavata njihove glasove, različne od Yeatsovega lastnega avtorskega glasu. Robartes in Aherne sta osrednja lika Yeatsovih najbolj ezoteričnih kratkih zgodb in oba kasneje $\mathrm{v}$ prvi osebi spregovorita $\mathrm{v}$ njegovi poeziji, ${ }^{9}$ srečamo pa ju tudi v Viziji $B$, ki naj bi jo Yeats sprva nameraval

\footnotetext{
${ }^{8}$ Tudi arhetipa norca (Fool) in puščavnika (Hermit), ki ju omenja Ellmann, sta $\mathrm{v}$ Yeatsovem imaginariju tesno povezana z ezoterično prakso $-\mathrm{s}$ tarotom, kjer predstavljata dve izmed podob velikih arcana (skrivnosti) pod številkama 0 (Norec) in IX (Puščavnik).

${ }^{9} \mathrm{~V}$ zgodbah "Rosa Alchemica", "Table postave" ("The Tables of the Law») in "Poklon treh modrih" ("The Adoration of the Magi«) ter pesmih "Dvojno videnje Michaela Robartesa" (»The Double Vision of Michael Robartes»), "Michael Robartes in plesalka» (»Michael Robartes and the Dancer»), „Owen Aherne in njegove plesalke» ("Owen Aherne and His Dancers) in "Lunine mene» (» The Phases of the Moon»).
} 
zapisati kot dialog med njima (Mills Harper in Paul 328). Kouredarei in Moghadam menita, da je Yeats »morda imel, ali vsaj želel, da bi njegovi bralci imeli ta lika za resnična posameznika, ki živita $\mathrm{v}$ istem svetu kot on sam in ne le v njegovem pisanju «, ter za to podajata več prepričljivih argumentov (Kouredarei in Moghadam 360). Robartes in Aherne v pesmi "Lunine mene" (»Phases of the Moon«) indirektno omenjata tudi Yeatsa. V Viziji najdemo pismo, naslovljeno na Yeatsa, ki naj bi ga napisal Ownov brat John Aherne (Yeats, $A$ Vision 38-40). In zdi se, kot da v eseju "Ljudsko gledališče» (»A People's Theatre») Yeats pripisuje Robartesu avtorstvo dveh svojih pesmi: "Ali se približujemo najvišjemu trenutku samozavedanja, ko si dve polovici duše ločeno stojita nasproti? Neki moj prijatelj je na to temo napisal dve zapleteni pesmi, naslovljeni 'Lunine mene' in 'Dvojno videnje', ki ju stalno preučujem [...] «(Yeats, "A People's« 210). Sklep, da bi Yeatsu morda morali pripisati uvedbo koncepta heteronimije $\mathrm{v}$ zahodni literarni kanon, je sicer nekoliko pretiran, vendar gre pri Ahernu in Robartesu resnično za obliko kreativne disociacije, ki se že skoraj bliža stopnji Pessoove.

Čeprav je k Yeatsovim maskam in Pessoovim heteronimom mogoče pristopati zgolj z vidika modernističnega poigravanja z literarnimi konvencijami, nam ezoterična perspektiva omogoči globlji uvid v njun ustvarjalni postopek. Na podlagi Pessoovih zapisov o heteronimih je težko s popolno gotovostjo trditi, na kakšen način je "soavtorje" doživljal sam in v kolikšni meri je avtonomnost, ki jim jo pripisuje, le rezultat njegovega umetniškega genija in ne tudi subjektivnih verovanj. Podobno, kot je Yeats prek komunikacije z Leom Africanom odkril in poimenoval svojo "masko", tudi Pessoovo prvo "srečanje» z Albertom Caeirom močno spominja na njegove opise medijstva. Iz njegovih "iniciacijskih" izkušenj (občutka, da nima nadzora nad lastnim telesom, spreminjanja obraza v zrcalu) razbiramo, da depersonalizacija pri Pessoi ni bila le literarna, temveč se je manifestirala $v$ dejanskih psihičnih stanjih, poleg tega pa vemo, da $v$ njej ni nujno videl motnje, temveč prebujanje do tedaj spečih čutov - prej višjo integracijo kot dezintegracijo.

Pessoa je heteronime razvil med letoma 1912 in 1914, približno $\mathrm{v}$ istem času, ko je Yeats pilil svoje maske. V pismu prijatelju Adolfu Casaisu Monteiru (13. 1. 1935) se spominja, kako se mu je leta 1912 ob pisanju pogansko naravnanih pesmi »V slabo tkanem somraku izrisal nejasen portret « osebe, ki jih je pisala: »Ne da bi vedel, se je rodil Ricardo Reis" (Pessoa, "Carta a Adolfo«). Šele slabi dve leti zatem je prišel na idejo, da bi si izmislil »bukoličnega pesnika zapletene vrste«, vendar je bil pri tem neuspešen, dokler se mu ni nenadoma »razodel « Caeiro: 
Nekega dne, [...] bil je 8. marec 1914 [...] sem vzel list papirja in pričel pisati stoje, kakor pišem zmeraj, kadar lahko. In na mah sem napisal več kot trideset pesmi v nekakšni ekstazi, katere narave ne morem opisati. [...] Zatem se je v meni pojavil nekdo, ki sem ga nemudoma poimenoval Alberto Caeiro. Oprostite mi za absurdnost te izjave: moj učitelj [mestre] se je pojavil v meni. [...] To je bila vrnitev Fernanda Pessoe Alberta Caeira samemu Fernandu Pessoi. Ali bolje, bila je reakcija Fernanda Pessoe proti svojemu neobstoju kot Alberto Caeiro (prav tam). ${ }^{10}$

Pomembno je poudariti, da je bila kreacija heteronimov sicer res zavestna, če ne povsem izoblikovana odločitev, vendar Pessoa z racionalnim pristopom ni prišel daleč. Tudi Reis se je rodil, vsaj kot osnutek, brez Pessoove zavestne udeležbe. Izkazalo se je, da si Pessoa Caeira ni mogel preprosto izmisliti - Caeiro je moral postati. Če uporabimo Yeatsovo terminologijo: utelesiti je moral svoj antijaz, da se mu je znova približal daemon. Pessoa je in hkrati $n i$ Caeiro oziroma Caeiro postane prav zato, ker to ni. Ekstaza, ki jo opisuje oziroma jo je nezmožen opisati, bi lahko bila preprosto nenaden naval pesniškega navdiha, vendar glede na podobnost $s$ Pessoovimi opisi medijstva ni nemogoče, da bi podobno doživljal pojavitev svojega notranjega učitelja. Vsaj za Caeira tako lahko rečemo, da za Pessoo ni bil nedvoumno le fragment njegove lastne osebnosti, temveč tudi nekakšna odtujena entiteta, ki je delovala skozenj. Prav tako ni nezanemarljivo, da na seznamih heteronimov običajno najdemo tudi Mora, Wardourja in Voodooista, Pessoove "sogovornike" v avtomatističnih seansah, kar dodatno zabrisuje mejo med njegovimi ezoteričnimi in literarnimi prizadevanji.

Čeprav zagotovo drži, kar pravi Bergles - da se Pessoa ni povsem brez pomislekov predajal okultizmu - in je res tudi to, da se pri interpretaciji nastanka heteronimov ne moremo in ne smemo zanesti samo na ezoterično perspektivo, pa je, če upoštevamo avtorsko intenco, vseeno mogoče polemizirati s trditvijo, da "gre le za žlahtno umetniško izmišljotino, za fikcijo« (Bergles 65). Pessoa sam pravzaprav trdi nasprotno:

Stvaritev Caeira in učenčevstva Reisa in Camposa se zdi na prvi pogled domiselna domišljijska šala. Vendar ni. To je veliko delo intelektualne magije, magnum opus neosebne ustvarjalne moči. Potrebujem vso koncentracijo, ki jo lahko zberem, za pripravo tega, čemur figurativno lahko rečemo dejanje intelektualne magije - torej za pripravo literarne stvaritve $\mathrm{v}$ tako rekoč četrti dimenziji uma (Pessoa, »The Creation« 248).

${ }^{10}$ Prim. prevod Mojce Medvešček v Pessoa, Psihotipija 424-425; in Cirila Berglesa v Bergles 63-64. 
Tudi pojem »četrta dimenzija« ni prost ezoteričnih konotacij. Pessoa je na njej utemeljil svojo teorijo senzacionizma, ${ }^{11}$ ki ga je poimenoval "umetnost štirih dimenzij», pri čemer je četrta dimenzija zmožnost reči, da so občutene. Izhajal je iz treh predpostavk:

1. Edina resničnost je občutek.

2. Maksimalna resničnost nam bo dana, če bomo čutili vse na vse načine (ob vsakem času).

3. Za ta namen je bilo nujno biti use in vsi (Pessoa, »1. Todos« 146).

Kot ugotavlja Patricia McNeill, je med možnimi viri za Pessoovo razumevanje četrte dimenzije tudi Leadbeaterjevo delo Jasnovidnost (Clairvoyance), ena od teozofskih knjig, ki jih je Pessoa prevedel leta 1916. Leadbeater četrto dimenzijo enači $\mathrm{z}$ astralnim vidom in piše o tem, da bi leseno kocko, če bi jo pogledali astralno, videli z vseh strani hkrati (Leadbeater v McNeill, "Sacred « 39). Frazo "čutiti vse na vse načine« uporablja tudi Álvaro de Campos v svoji senzacionistični odi »Prehajanje ur» (»A Passagem das Horas»):

Sentir tudo de todas as maneiras,

Viver tudo de todos os lados,

Ser a mesma coisa de todos os modos possíveis ao mesmo tempo,

Realizar em si toda a humanidade de todos os momentos

Num só momento [...] (Pessoa, »Sentir«26a).

Čutiti vse na vse načine,

živeti vse $\mathrm{z}$ vseh strani,

biti ista stvar v vseh mogočih pogledih hkrati,

realizirati v sebi vse človeštvo vseh trenutkov

v enem samem trenutku [...] (Pessoa, Psihotipija 75; prevod Miklavža Komelja).

Čutiti vse na vse načine pa zahteva pomnožitev, biti vse in vsi: "Pomnožil sem se, da bi se čutil, / da bi se čutil, sem moral čutiti vse" (Pessoa, Psihotipija 76). Pessoovo občutje razcepljenosti, še več, njegovo hrepenenje po še večji razcepljenosti, ki bi bila paradoksno enotna celota bivanja, enakovredno občutijo tudi njegovi heteronimi. V "Čuvarju čred» (»O Guardador de Rebanhos«), prav tistem ciklu, ki se je polzavestno izlil iz Pessoe ob prvi pojavitvi Alberta Caeira, Caeiro piše: "včasih [si] v predstavi zaželim, da bi bil jagenjček (ali da bi bil vsa

${ }^{11}$ Poleg pavlizma in intersekcionizma eden od Pessoovih izvirnih umetniških »izmov«. 
čreda, da bi šel razkropljen po vsem pobočju, da bi bil mnogo srečnih stvari hkrati) «(9); in božjo prisotnost razdrobi v več različnih naravnih pojavnosti: "če so Bog rože in drevesa in gore in sonce in mesečina, potem verjamem vanj" (18). Če se sklicujemo na njegove panteistične nagibe, bi lahko rekli, da so za Pessoo na neki način vse bivajoče stvari božji heteronimi, fragmenti prvobitne enosti. Pessoovo četrto dimenzijo lahko kot Leadbeater razumemo kot astralni vid ali celo kot vseobsegajoči božji pogled. Edini način, da človek uzre več plati resničnosti, kot jih omogoča uzreti običajna zavest, je za Pessoo pomnožitev, »razparceliranje« sebstva. Vse to kaže na globlji, metafizični izvor heteronimov, primerljiv z ezoteričnim pojmom transmutacije. Pessoa je udejanjil Yeatsovo teorijo maske v njeni absolutni skrajnosti. Tisto, kar je bilo pri Yeatsu sredstvo za doseganje navdiha, pri Pessoi tako rekoč zaživi svoje lastno življenje. Z drugimi besedami: Pessoa se je odločil za nevarnejšo pot, saj njegove maske niso začasne. Šel je celo tako daleč, da je sam postal maska, ontološko krhek Fernando Pessoa-heteronim v coterie Fernanda Pessoe samega. Tudi Pessoa sam je le ena izmed oseb v množici in hkrati vse med njimi, njegova heteronimija je specifična konstrukcija vzajemnega ustvarjanja in popisovanja, v kateri maska zmeraj znova razkrije novo masko.

Vidimo, da je imela kreativna disociacija veliko vlogo tako v Yeatsovem kot v Pessoovem pesniškem postopku, ki je imel za oba ezoterične podtone. Za Yeatsa se je pričel kot svojevrsten magijski ritual: $\mathrm{z}$ evokacijo daemona, nosilca navdiha, prek maske antijaza, Pessoova ustvarjalna prelomnica pa je bila še bolj intenzivna - invokacija njegovega "mojstra" Alberta Caeira. Kot poudarja Pasi, je bila »izkušnja disolucije individualnega jaza in objektivne realnosti $\mathrm{v}$ veliki meri del tedanjega modernističnega diskurza [...] in jo pogosto lahko najdemo v kombinaciji z zanimanjem za ezoterizem" (Pasi, „Hilma« 111). $V$ luči zahodnega ezoterizma se nam tako razkrijejo nove dimenzije modernističnega ustvarjanja. Yeatsova in Pessoova disociativna stanja, pa tudi njune "duhovne mentorje«, sicer lahko razumemo, kot da so zgolj psihološkega (in ne parapsihološkega) izvora, vendar pri tem zanemarimo njuno videnje lastnega delovanja in ustvarjanja. Če avtorja ne "usmrtimo" popolnoma, bi morali resno jemati vse plati njegove osebnosti - oziroma v Pessoovem, delno pa tudi Yeatsovem primeru, vse njegove osebnosti. 


\section{LITERATURA}

Bergles, Ciril. "Velika Pessoova oda pomorščakom«. Spremna beseda. Pomorska odal Ode Marítima. Fernando Pessoa. Prev. Ciril Bergles. Ljubljana: Škuc, 2002. 59-67.

Bogdan, Henrik. Western Esotericism and Rituals of Initiation. Albany: State University of New York Press, 2007.

Dix, Steffen. "Democratization and the Aristocracy of the Occult: Fernando Pessoa between Theosophy and Rosacrucianism«. Pessoa Plural 6 (2014): 1-19.

Ellmann, Richard. Yeats: The Man and the Masks. New York: W. W. Norton \& Co, 2000.

Ellmann, Richard. »Robartes and Aherne: Two Sides of a Penny«. The Kenyon Review 10.2 (1948): 177-186.

Faivre, Antoine. Access to Western Esotericism. Albany: State University of New York Press, 1994.

Flannery, Mary C. Yeats and Magic: The Early Works. London: Colin Smythe, 1977.

Ghahremani Kouredarei, Hamid, in Nahid Shahbazi Moghadam. "W. B. Yeats and the Introduction of Heteronym into the Western Literary Canon". Studi Irlandesi: A Journal of Irish Studies 8.8 (2018): 357-375.

Grosso, Michael. »Inspiration, Mediumship, Surrealism: The Concept of Creative Dissociation«. Broken Images, Broken Selves: Dissociative Narratives in Clinical Practice. Ur. Stanley Krippner in Susan Marie Powers. Bristol: Brunner/Mazel, 1997. 181-198.

Hanegraaff, Wouter J. New Age Religion and Western Culture: Esotericism in the Mirror of Secular Thought. Leiden: Brill, 1996.

Hanegraaff, Wouter J. Western Esotericism: A Guide for the Perplexed. London: Bloomsbury Academic, 2013.

Johnston Graf, Susan. W. B. Yeats - Twentieth-Century Magus. York Beach: Samuel Weiser, 2000.

Kotowicz, Zbigniew. Fernando Pessoa: Voices of a Nomadic Soul. Exeter; London: Shearsman Books; The Menard Press, 2008.

McNeill, Patrícia Silva. »The Alchemical Path: Esoteric Influence in the Works of Fernando Pessoa and W. B. Yeats«. Fernando Pessoa's Modernity Without Frontiers: Influences, Dialogues and Responses. Ur. Mariana Gray de Castro. Woodbridge: Tamesis, 2013. 157-168.

McNeill, Patrícia Silva. "Sacred Geometry of Being: Pessoa's Esoteric Imagery and the Geometry of Modernism«. Pessoa Plural 6 (2014): 21-45.

McNeill, Patrícia Silva. Yeats and Pessoa: Parallel Poetic Styles. London: Legenda, 2010.

Mills Harper, Margaret, in Catherine E. Paul. "Notes«. A Vision: The Revised 1937 Edition. W. B. Yeats. Ur. Margaret Mills Harper in Catherine E. Paul. New York: Scribner, 2015. 299-468.

Pasi, Marco. Aleister Crowley and the Temptation of Politics. Abingdon: Routledge, 2014.

Pasi, Marco. »Hilma af Klint, Western Esotericism and the Problem of Modern Artistic Creativity". Hilma af Klint: The Art of Seeing the Invisible. Ur. Kurt Almqvist in Louise Belfrage. Stockholm: Axel and Margaret Ax:son Johnson Foundation, 2015. 101-116.

Pasi, Marco. "The Influence of Aleister Crowley on Fernando Pessoa's Esoteric Writings". Esoterisme, Gnoses et Imaginaire Symbolique: Mélanges offerts à Antoine Faivre. Leuven: Peeters, 2001. 693-711. 
Pessoa, Fernando. »Carta a Adolfo Casais Monteiro - 13 Jan. 1935«. Escritos Íntimos, Cartas e Páginas Autobiográficas. Ur. António Quadros. Mem Martins: Publicaçóes Europa-América, 1986. 199.

Pessoa, Fernando. "Carta à Tia Anica - 24 Jun. 1916«. Escritos Íntimos, Cartas e Páginas Autobiográficas. Ur. António Quadros. Mem Martins: Publicaçôes Europa-América, 1986. 127.

Pessoa, Fernando. "The Creation of Caeiro and of the Discipleship of Reis and Campos...". Pessoa por Conhecer - Textos para um novo Novo Mapa. Ur. Teresa Rita Lopes. Lizbona: Estampa, 1990. 248.

Pessoa, Fernando. »Nota Biográfica«. Escritos Íntimos, Cartas e Páginas Autobiográficas. Ur. António Quadros. Mem Martins: Publicaçōes Europa-América, 1986. 252.

Pessoa, Fernando. Psihotipija: izbrano delo. Prev. Miklavž Komelj, Mojca Medvešček in Ciril Bergles. Ljubljana: Mladinska knjiga, 2007.

Pessoa, Fernando. "Sentir tudo de todas as maneiras«. Álvaro de Campos - Livro de Versos. Ur. Teresa Rita Lopes. Lizbona: Estampa, 1993. 26 .

Pessoa, Fernando. »Tábua Bibliográfica«. Presença 17 (1928): 250.

Pessoa, Fernando. »1. Todos os fenómenos se passam no espaço«. Pessoa Inédito. Ur. Teresa Rita Lopes. Lizbona: Livros Horizonte, 1993. 146.

Regardie, Israel. The Golden Dawn: The Original Account of the Teachings, Rites and Ceremonies of the Hermetic Order of the Golden Dawn (Stella Matutina). St. Paul: Llewellyn, 2005.

Steiner, George. "A Man of Many Parts«. The Observer. 3. 6. 2001. <https://www. theguardian.com/books/2001/jun/03/poetry.features1>

Suaréz, José I. »Fernando Pessoa's Acknowledged Involvement with the Occult«. Hispania 90.2 (2007): 245-252.

Yeats, William Butler. "Magic«. Early Essays. Ur. George Bornstein in Richard J. Finneran. New York: Simon \& Schuster, 2007. 25-41.

Yeats, William Butler. "A People's Theatre: A Letter to Lady Gregory». The Collected Works of W. B. Yeats: The Irish Dramatic Movement. Ur. Mary FitzGerald in Richard J. Finneran. New York: Simon \& Schuster, 2003. 197-213.

Yeats, William Butler. Per Amica Silentia Lunae. New York: Macmillan, 1918.

Yeats, William Butler. "Rosa Alchemica«. The Secret Rose, Stories by W. B. Yeats: A Variorum Edition. Ur. Warwick Gould, Phillip L. Marcus in Michael J. Sidnell. London: Palgrave Macmillan, 1992. 126-150.

Yeats, William Butler. A Vision: The Revised 1937 Edition. Ur. Margaret Mills Harper in Catherine E. Paul. New York: Scribner, 2015. 


\section{Yeats's Masks and Pessoa's Heteronyms in the Light of Western Esotericism}

Keywords: Irish literature / Portuguese literature / modernism / Yeats, William Butler / Pessoa, Fernando / Western esotericism / occultism / the Mask / heteronyms

The article deals with the influence of Western esotericism and occultism on the life and works of William Butler Yeats and Fernando Pessoa, particularly on their poetic technique of "creative dissociation" or "depersonalization" (which is how Pessoa described his heteronymy). This technique is the main shared characteristic of Yeats's and Pessoa's poetics, which is not only paradigmatically modernist but also emphatically esoteric. The term "esoteric" here refers to different currents that evolved throughout history in parallel with organized religion, on the one hand, and Enlightenment rationalism on the other, forming the so-called third pillar of Western culture. Yeats based his theory of the Mask on the ideas he developed during his years as a member of the Hermetic Order of the Golden Dawn, while Pessoa's practice of spiritualism, mediumship, and automatic writing influenced his creation of heteronyms. In this regard, we can view the work of both authors as a modernist artistic expression that was formed in close contact with Western esotericism.

1.01 Izvirni znanstveni članek / Original scientific article

UDK 82.091

821.111.09Yeats W. B.

821.134.3.09Pessoa F.

DOI: https://doi.org/10.3986/pkn.v43.i3.07 